\title{
Distribution and ecology of the stoneflies (Plecoptera) of Flanders (Belgium)
}

\author{
K. Lock, P.L.M. Goethals
}

Ghent University, Laboratory of Environmental Toxicology and Aquatic Ecology, J. Plateaustraat 22, 9000 Gent, Belgium.

\begin{abstract}
Based on a literature survey and the identification of all available collection material from Flanders, a checklist is presented, distribution maps are plotted and the relationship between the occurrence of the different species and water characteristics is analysed. Of the sixteen stonefly species that have been recorded, three are now extinct in Flanders (Isogenus nubecula, Taeniopteryx nebulosa and T. schoenemundi), while the remaining species are rare. The occurrence of stoneflies is almost restricted to small brooks, while observations in larger watercourses are almost lacking. Although a few records may indicate that some larger watercourses have recently been recolonised, these observations consisted of single specimens and might be due to drift. Most stonefly population are strongly isolated and therefore extremely vulnerable. Small brooks in the Campine region (northeast Flanders), which are characterised by a lower $\mathrm{pH}$ and a lower conductivity, contained a different stonefly community than the small brooks in the rest of Flanders. Leuctra pseudosignifera, Nemoura marginata and Protonemura intricata are mainly found in small brooks in the loamy region, Amphinemura standfussi, Isoperla grammatica, Leuctra fusca, L. hippopus, N. avicularis and P. meyeri mainly occur in small Campine brooks, while L. nigra, N. cinerea and Nemurella pictetii can be found in both types. Nemoura dubitans can typically be found in stagnant water fed with freatic water. Sustainable populations of these stonefly species can only be achieved when their present habitats are adequately protected and in addition, measures should be taken to connect and enlarge the remaining populations.
\end{abstract}

Keywords: ecoregions, checklist, distribution maps, phenology

\section{Introduction}

The main objective of the European Water Framework Directive (EWFD) is to achieve a good ecological status of groundwater and surface water in Europe by 2015 (European Council 2000). For natural waters, this objective is more specifically described as the attainment of a good ecological and chemical status. The ecological status of each type of water body has to be defined based on near-natural reference conditions. The EWFD requires the use of biotic indicators, such as macrobenthic fauna, fish fauna and aquatic flora, to assess water quality.

In the past, the Flemish Environment Agency used the Belgian Biotic Index (BBI; De Pauw \& Vanhooren 1983), which has been adopted as a standard method for assessing river water quality by means of macroinvertebrates by the Belgian Institute of Normalization (IBN

* Corresponding author : E-mai : Koen.Lock@UGent.be
1984). Recently, however, the Multimetric Macroinvertebrate Index Flanders (MMIF; Gabriels et al. 2006) was developed in order to meet the requirements of the EWFD. In both indexes, stoneflies are recognised as the most sensitive group of water invertebrates, which only occur in waters with a high water quality.

Despite their importance as water quality indicators, stoneflies have hardly received any attention in Flanders. In the present study, an overview of the available literature is given, a checklist of the stoneflies occurring in Flanders is presented, distribution maps for all species are plotted and the relationship between the occurrence of the different species and the water characteristics was analysed.

\section{Materials and methods}

All available Plecoptera from Flanders and Brussels were identified to species level using the identification keys by Aubert (1959) and Illies (1955). The largest 
collection was present in the Royal Belgian Institute for Natural Sciences, where also the material of the Flemish Environment Agency is conserved. Some smaller collections were present at Antwerp University, where the collection of the Flemish Entomological Society is kept, in the Laboratory of Environmental Toxicology and Aquatic Ecology at Ghent University and at the Gembloux Agricultural University.

In the context of water quality monitoring by the Flemish Environment Agency, macroinvertebrates have been sampled at several thousand sampling points since 1989. During monitoring, macroinvertebrates are sampled using a standard handnet, as described by De Pauw \& Vanhooren (1983) and IBN (1984). With the handnet, a stretch of 10-20 meters is sampled during approximately five minutes. Sampling effort is proportionally distributed over all accessible aquatic habitats. This includes the bed substrate (stones, sand or mud), macrophytes (floating, submerging, emerging), immersed roots of overhanging trees and all other natural or artificial substrates, floating or submerged in the water. Each aquatic habitat is explored, in order to collect the highest possible diversity of macroinvertebrates. For this purpose, kicksampling is performed. In addition to the handnet sampling, animals are manually picked from stones, leafs or branches (De Pauw \& Vanhooren 1983). Conductivity, pH, oxygen content and water temperature are measured at each sampling point.

In Flanders, a typology of the watercourses has been made by Jochems et al. (2002). The main separation of the types is based on the catchment area and in addition, the watercourses in the polder area are separated from the remaining watercourses and also the small and large brooks of the Campine area are separated from the small and large brooks in the rest of Flanders. The different types of watercourses are listed in Table 2 and a map of Flanders with indication of the ecoregions is presented in Fig. 1.

To analyse the distribution, phenology and ecology of stoneflies, literature data as well as all available data from the collections and the water quality monitoring data from the Flemish Environment Agency were brought together in one dataset. However, only the monitoring data could be linked to environmental variables. The Canonical Correspondence Analysis (CCA) option from the program package CANOCO (Ter Braak 1988) was applied to determine which environmental parameters might be responsible for the differences in species composition. A log-transformation was applied prior to the CCA to normalise the data.

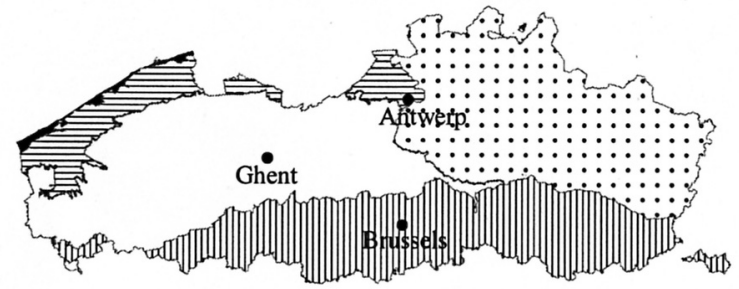

Fig. 1. Map of Flanders with indication of the different ecoregions: dune area (black), polder area (horizontal stripes), sandy region (white), Campine region (dots) and loamy region (vertical stripes).

\section{Results}

Despite their value as biological indicators of a good water quality, hardly any data have been published about the stoneflies in Flanders. De Selys-Longchamps (1888) reported three species from the river Meuse: Isogenus nubecula, Isoperla grammatica and Nemoura cinerea. $\mathrm{He}$ also reported Protonemura lateralis from RougeCloître in Forêt de Soignes, close to Brussels, however, this consisted probably of $P$. intricata, which is the only species of Protonemura that could be confirmed for this region. Lestage (1921) reported the presence of exuviae of Taeniopteryx nebulosa from the Dommel in Neerpelt. Although Lestage (1938a,b) observed that these specimens had a variable number of processes on the abdominal tergites, he could not believe two different species occurred together. However, Aubert (1950) indicated that T. nebulosa and T. schoenemundi could occur together in Belgium and during the present study it could be confirmed that the material collected by Lestage (deposited in the Royal Belgian Institute of Natural Sciences) consisted of specimens from both species. Demoulin (1953) reported three species from Schelderode: Nemoura cinerea, Amphinemura sulcicollis and Protonemura species, however, A. sulcicollis turned out to be A. standfussi, while no specimens of the genus Protonemura could be found in the collection of Demoulin (deposited in the Royal Belgian Institute of Natural Sciences). Aubert $(1956,1957)$ summarised the available Plecoptera data for Belgium and reported the following species for Flanders and Brussels: Amphinemura standfussi, Nemoura cinerea, N. dubitans, $N$. marginata, Nemurella pictetii, Protonemura intricata and Isogenus nubecula. He also reported Marthamea selysii, Isoptena serricornis and Xanthoperla apicalis from Limburg, however, these records were actually 
from the Netherlands, which also contains a region called Limburg. Grootaert \& Verbeke (1983) found Nemoura cinerea in Zedelgem. No stonefly observations from Flanders have been published recently.

For this study, 8931 stoneflies were identified: 524 adults, 132 exuviae and 8275 larvae. They represent 562 records of which only 147 date from before 1990 and 415 since 1990 . Of the 16 species that were recorded for Flanders and Brussels (Table 1), six were not previously reported: Leuctra fusca, L. hippopus, L. nigra, L. pseudosignifera, Nemoura avicularis and P. meyeri. L. pseudosignifera is also a new species for the Belgian fauna. In the capital region of Brussels, five species had been reported: Nemoura cinera, $N$. dubitans, $N$. marginata, Nemurella pictetii and Protonemura intricata, however, the latter species was not observed since 1942. In the remainder of this paper, the records from Brussels will be treated together with those from Flanders.

Most stoneflies were found in small brooks and small Campine brooks, while hardly any observations were done in larger rivers (Table 2). In large brooks and polder watercourses only one larvae of Nemoura cinerea was ever found: in 1983 in the Demer and in 1982 in the polders of De Haan, respectively. Also in large Campine brooks, only a few stoneflies were observed: in 1921 Taeniopteryx schoenemundi and T. nebulosa exuviae were collected in the Dommel, in the Mangelbeek one larvae of Amphinemura standfussi was caught in 2004, in the Grote Nete five Nemoura avicularis larvae were captured in 1979 and another one in 2005. In small and large rivers, no stoneflies have ever been observed in Flanders. In the only very large river in Flanders, the river Meuse, Nemoura cinerea, Isogenus nubecula and Isoperla grammatica were recorded in the nineteenth century (De Selys-Longchamps 1888), but no Plecoptera were observed in the twentieth century, however, one larvae of Leuctra nigra was captured in 2004.

Of the 16 species in Flanders, 3 species were not observed since 1990: Isogenus nubecula, Taeniopteryx nebulosa and T. schoenemundi (Fig. 2). The 13 remaining species have a restricted distribution (Fig. 2). Most stoneflies in Flanders have their main flight period during spring (Table 3). Leuctra fusca is the only species in Flanders which emerges exclusively in autumn, while Taeniopteryx nebulosa and T. schoenemundi are already adult in winter.

Stoneflies were mainly found in waters with a high oxygen content (Fig. 3). Ubiquitous species such as Nemoura cinerea and Nemurella pictetii could also live in waters with somewhat lower oxygen concentrations, however, no stoneflies were observed in waters with an oxygen content under $4 \mathrm{mg} . \mathrm{l}^{-1}$. Several species, such as L. hippopus and P. meyeri, were mainly found in the Campine region, where watercourses contained acid or circumneutral water with a relatively low conductivity (Fig. 3). Other species, such as $N$. marginata and $P$. intricata, mainly occurred in the loamy region, where watercourses contained alcalic water with a higher conductivity (Fig. 3).

In a biplot of the sample scores and the environmental variables, the first and the second axis had an Eigenvalue of 0.443 and 0.359 , respectively. Conductivity and $\mathrm{pH}$ explained most of the variance in the species composition of the stoneflies, while the oxygen content was less important (Fig. 4). The samples from the small Campine brooks, with on average a lower $\mathrm{pH}$ and a lower conductivity were clearly separated from the small brooks. Leuctra pseudosifnifera, Nemoura marginata and Protonemura intricata were characteristic for the small brooks in the loamy region, $N$. cinerea and Nemurella pictetii were ubiquitous species that tolerated somewhat lower oxygen concentrations, while all other species were characteristic for small Campine brooks (Fig. 4).

\section{Discussion}

Using the categories proposed by the IUCN Species Survival Commission (IUCN Species Survival Commission 1994) and adapted for Flanders (Maes et al. 2003, Maes \& Van Swaay 1997), the stoneflies were divided into categories according their rarity. Of the 16 species that have been reported (Table 1), three species are extinct in Flanders: Isogenus nubecula has not been observed since it was recorded by De Selys-Longchamps (1888), Taeniopteryx schoenemundi was last found in 1921 and T. nebulosa has not been observed since 1982. Most of the remaining species are very rare and occur in less than two percent of the $5 * 5 \mathrm{~km}$ UTM squares. Nemoura marginata and Nemurella pictetii are somewhat more common, but are still rare, occurring in less than five percent of the squares. The most common species in Flanders is Nemoura cinerea, however, even this species is fairly rare as it occurs in less than 15 percent of the squares. Insufficient historical data are available to calculate trends and therefore, no red list is presented. However, it is obvious that most remaining stonefly species in Flanders are vulnerable, if not endangered.

In the Netherlands, 27 species have been observed of which 17 are now extinct in The Netherlands (Claessens 1981, Koese 2008). Of the remaining species, 
Order Plecoptera

Suborder Arctoperlaria

Superfamily Perloidea

Family Perlodidae

Subfamily Isoperlinae

1. Isoperla grammatica (Poda 1761)

Subfamily Perlodinae

2. Isogenus nubecula Newman 1833

Superfamily Nemouroidea

Family Taeniopterygidae

Subfamily Taeniopteryginae

3. Taeniopteryx nebulosa (Linnaeus 1758)

4. Taeniopteryx schoenemundi Mertens 1923

Family Nemouridae

Subfamily Amphinemurinae

5. Amphinemura standfussi (Ris 1902)

6. Protonemura intricata (Ris 1902)

7. Protonemura meyeri (Pictet 1841)

Subfamily Nemourinae

8. Nemoura avicularis Morton 1894

9. Nemoura cinerea (Retzius 1783)

10. Nemoura dubitans Morton 1894

11. Nemoura marginata Pictet 1836

12. Nemurella pictetii Klapálek 1900

Family Leuctridae

Subfamily Leuctrinae

13. Leuctra fusca (Linnaeus 1758)

14. Leuctra hippopus Kempny 1899

15. Leuctra nigra (Olivier 1811)

16. Leuctra pseudosignifera Aubert 1954 
Table 2. Number of records in each of the eight river types that were recognised in Flanders (Jochems et al., 2002).

\begin{tabular}{|c|c|c|c|c|c|c|c|c|}
\hline River type: & $\begin{array}{l}\text { Very } \\
\text { large } \\
\text { river }\end{array}$ & $\begin{array}{c}\text { Large } \\
\text { river }\end{array}$ & $\begin{array}{c}\text { Small } \\
\text { river }\end{array}$ & $\begin{array}{l}\text { Large } \\
\text { brook }\end{array}$ & $\begin{array}{l}\text { Small } \\
\text { brook }\end{array}$ & $\begin{array}{c}\text { Large } \\
\text { Campine } \\
\text { brook }\end{array}$ & $\begin{array}{c}\text { Small } \\
\text { Campine } \\
\text { brook }\end{array}$ & $\begin{array}{l}\text { Polder } \\
\text { water- } \\
\text { course }\end{array}$ \\
\hline Catchment area $\left(\mathrm{km}^{2}\right)$ : & $>10000$ & $\begin{array}{c}600- \\
10000\end{array}$ & $\begin{array}{c}300- \\
600\end{array}$ & $50-300$ & $<50$ & $50-300$ & $<50$ & $\begin{array}{c}\text { Not } \\
\text { applicable }\end{array}$ \\
\hline Amphinemura standfussi & & & & & 2 & 1 & 23 & \\
\hline Isogenus nubecula & 2 & & & & & & & \\
\hline Isoperla grammatica & 4 & & & & & & 10 & \\
\hline Leuctra fusca & & & & & & & 6 & \\
\hline Leuctra hippopus & & & & & & & 7 & \\
\hline Leuctra nigra & 1 & & & & 15 & & 13 & \\
\hline Leuctra pseudosignifera & & & & & 3 & & & \\
\hline Nemoura avicularis & & & & & & 2 & 51 & \\
\hline Nemoura cinerea & 1 & & & 1 & 86 & & 122 & 1 \\
\hline Nemoura dubitans & & & & & 20 & & 3 & \\
\hline Nemoura marginata & & & & & 79 & & & \\
\hline Nemurella pictetii & & & & & 32 & & 52 & \\
\hline Protonemura intricata & & & & & 18 & & & \\
\hline Protonemura meyeri & & & & & & & 4 & \\
\hline Taeniopteryx nebulosa & & & & & & 1 & 1 & \\
\hline Taeniopteryx schoenemundi & & & & & & 1 & & \\
\hline Total number of species & 4 & 0 & 0 & 1 & 8 & 4 & 11 & 1 \\
\hline
\end{tabular}

nine are threatened while only one species (Nemoura cinerea) is considered as currently not under threat (Bal et al. 2001). From the species that are extinct in Flanders, Isogenus nubecula was last observed in the Netherlands in 1936 and Taeniopteryx nebulosa has not been reported there since 1954, while T. schoenemundi has never been observed in the Netherlands (Claessens 1981). Also from Wallonia these species have not been reported recently, however, this may be due to a lack of recent data for this region. Recolonisation of Flanders by these species will thus be difficult.

The fact that only 10 stonefly species still survive in the Netherlands of the 27 species that used to live there, indicates that almost certainly more than 16 species once occurred in Flanders. However, due to the lack of historical records, a lot of species were probably already extinct before they were ever identified. Species such as Marthamea selysii and Xanthoperla apicalis, which occurred in the river Meuse in the Netherlands as well as in Wallonia (Aubert 1956, Claessens 1981), undoubtly also lived in the Flemish part of the river Meuse.

Because the network of the Flemish Environment Agency is very elaborate, it can be assumed that the maps give a good idea of the present distribution of the stonefly species. One exception might be $N$. dubitans, which typically can be found in stagnant water fed with freatic water. This type of waters is not monitored routinely by the Flemish Environment Agency and therefore, this species has probably a somewhat larger distribution than indicated.

The occurrence of stoneflies in Flanders is almost restricted to small brooks and small Campine brooks, 

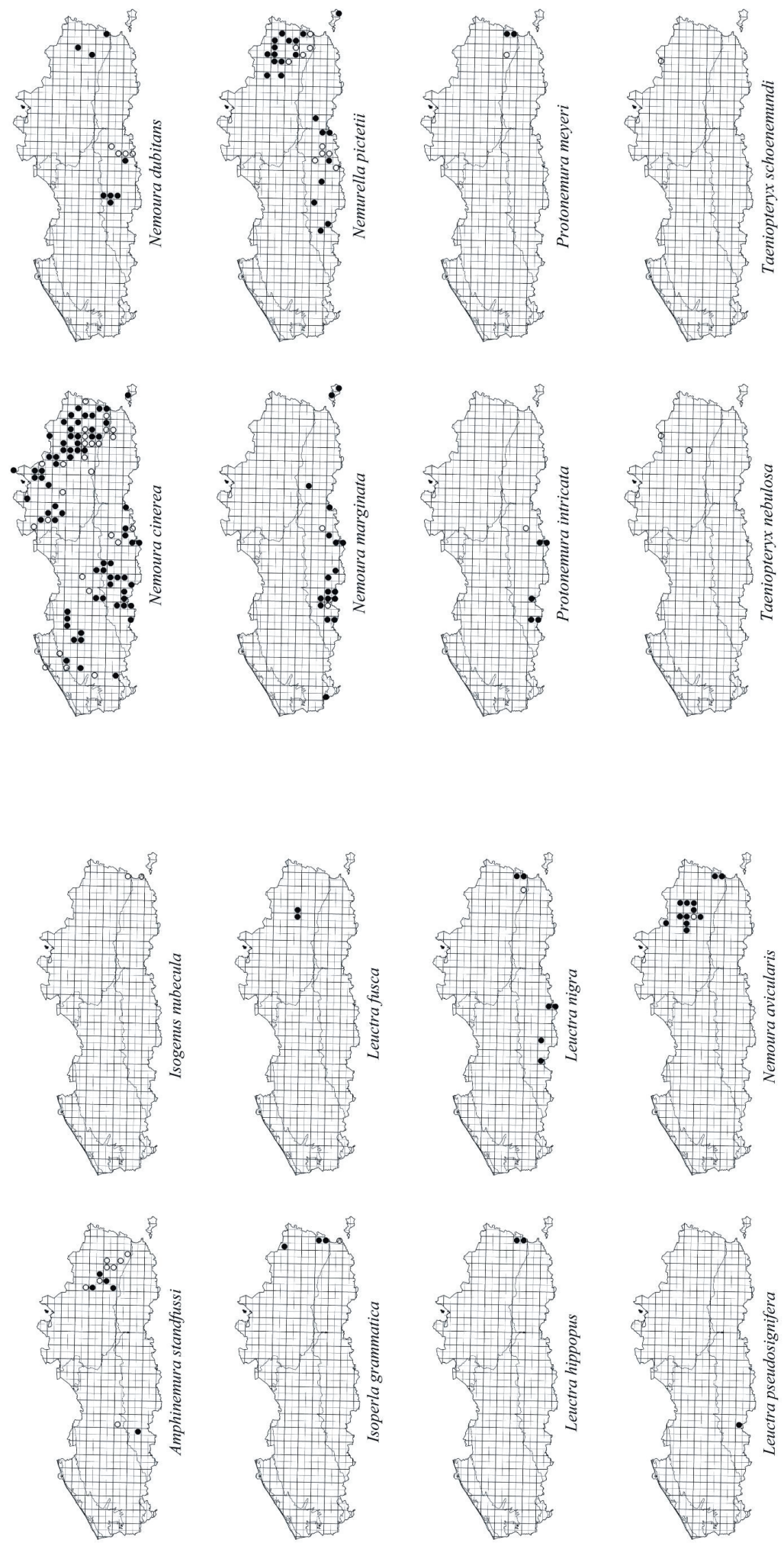

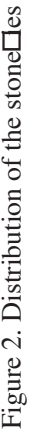



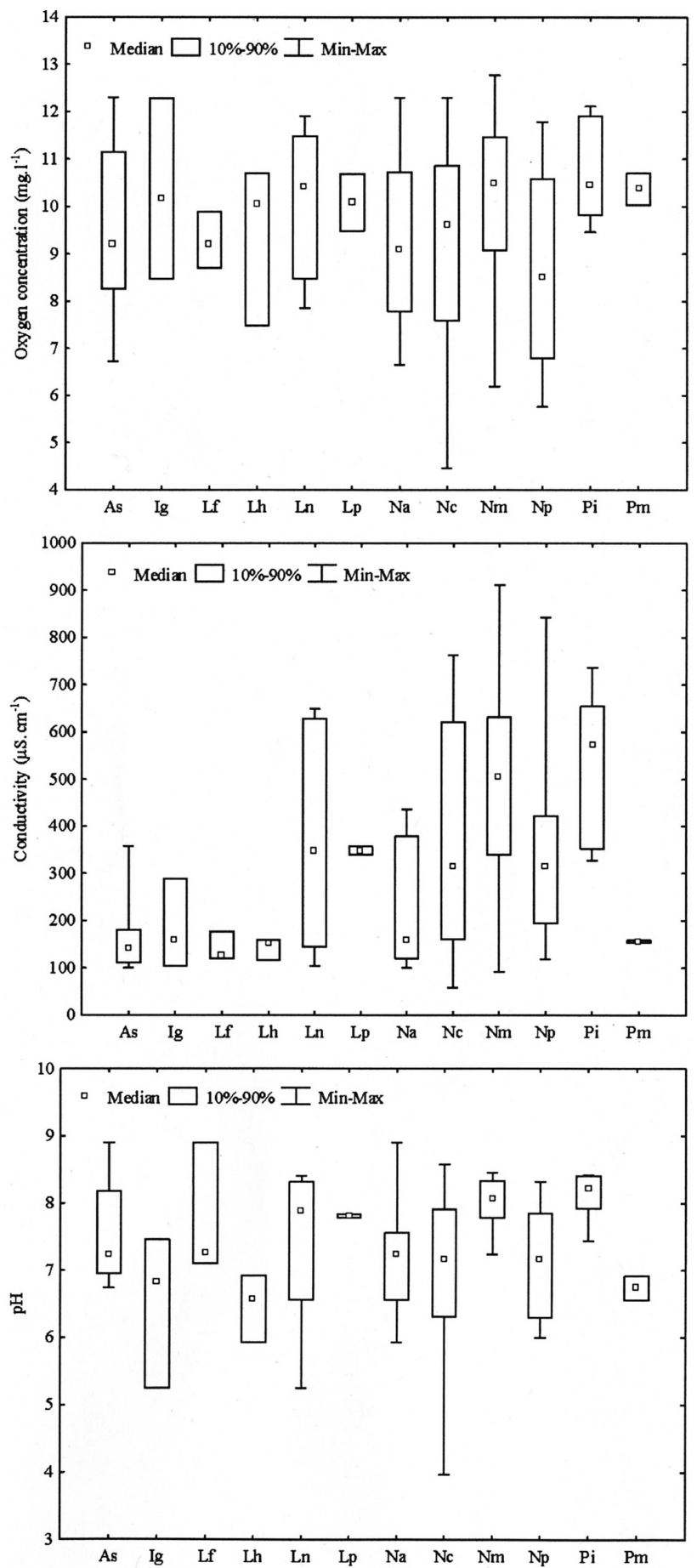

Fig. 3.Box \& Whisker plots of oxygen concentration, conductivity and $\mathrm{pH}$ in the watercourses containing Amphinemura standfussi (As, $\mathrm{N}=13$ ), Isoperla grammatica $(\mathrm{Ig}, \mathrm{N}=6)$, Leuctra fusca $(\mathrm{Lf}, \mathrm{N}=5)$, L. hippopus $(\mathrm{Lh}, \mathrm{N}=3)$, L. nigra $(\mathrm{Ln}, \mathrm{N}=16)$, L. pseudosignifera $(\mathrm{Lp}, \mathrm{N}=2)$, Nemoura avicularis $(\mathrm{Na}, \mathrm{N}=42), N$. cinerea $(\mathrm{Nc}, \mathrm{N}=92), N$. marginata $(\mathrm{Nm}, \mathrm{N}=53)$, Nemurella pictetii $(\mathrm{Np}, \mathrm{N}=42)$, Protonemura intricata $(\mathrm{Pi}, \mathrm{N}=15)$ and P. meyeri $(\mathrm{Pm}, \mathrm{N}=2)$. 


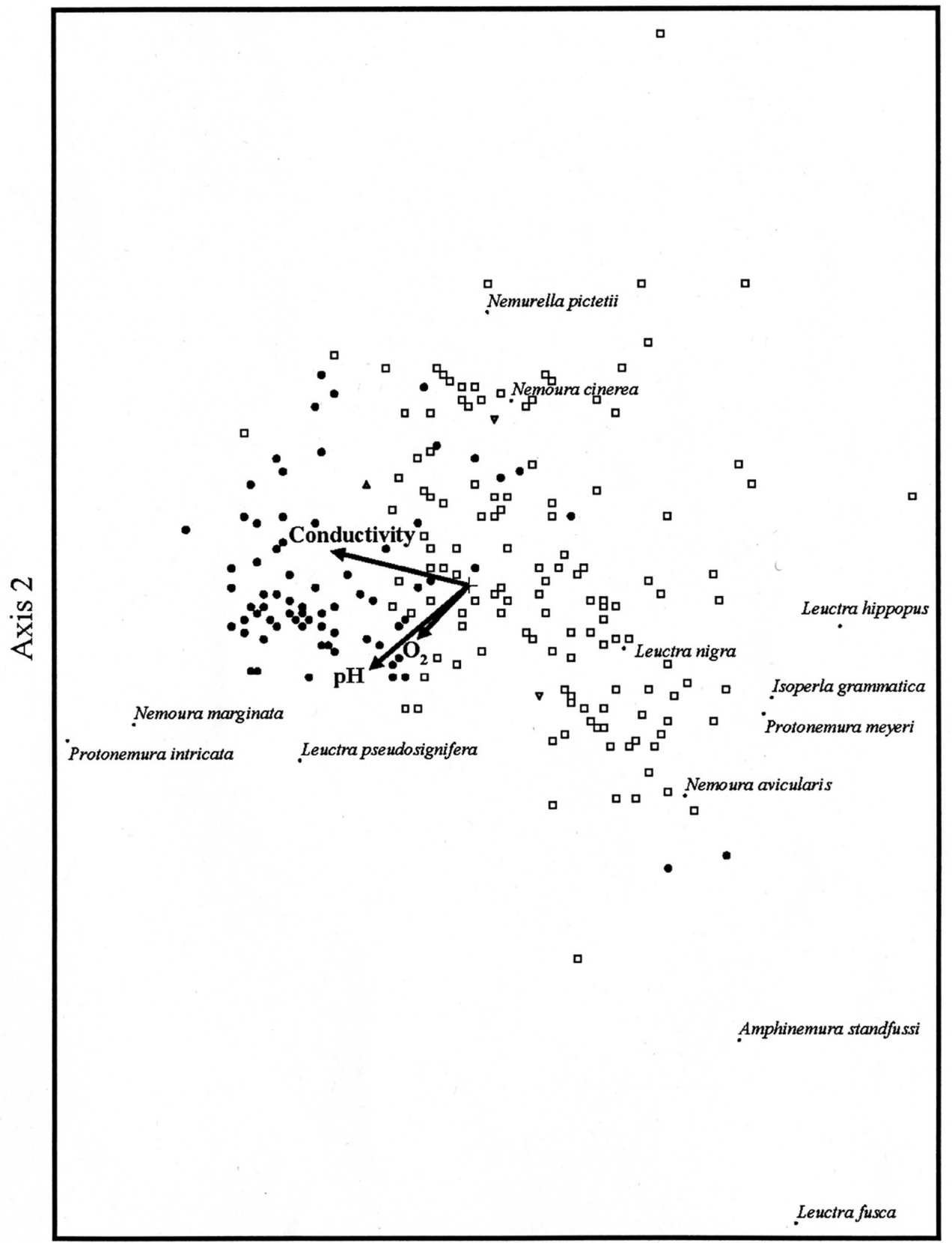

Axis 1

Fig. 4. Biplot of the sample scores and the environmental variables $\mathrm{pH}$, conductivity and oxygen concentration, with indication of the river types: small brook $(\bullet)$, small Campine brook (口), large Campine brook ( $\mathbf{v})$ and very large river $(\mathbf{\Delta})$. 
Table 3. Number of larvae (L), exuviae (E) and adults (A) of each species that were recorded during each month of the year.

\begin{tabular}{|c|c|c|c|c|c|c|c|c|c|c|c|c|c|}
\hline & & 1 & 2 & 3 & 4 & 5 & 6 & 7 & 8 & 9 & 10 & 11 & 12 \\
\hline \multirow[t]{2}{*}{ Amphinemura standfussi } & $\mathrm{L}$ & & & 6 & 27 & 130 & 72 & 1 & 6 & 1 & 1 & & \\
\hline & A & & & & & 24 & & & 1 & & & & \\
\hline Isogenus nubecula & A & & & & & 2 & & & & & & & \\
\hline \multirow[t]{2}{*}{ Isoperla grammatica } & $\mathrm{L}$ & & & 4 & 16 & 1 & 5 & & & 2 & & & \\
\hline & A & & & & & 4 & & & & & & & \\
\hline \multirow[t]{2}{*}{ Leuctra fusca } & $\mathrm{L}$ & & & & & 1 & 14 & & & 17 & & 2 & \\
\hline & A & & & & & & & & & 4 & & & \\
\hline \multirow[t]{2}{*}{ Leuctra hippopus } & $\mathrm{L}$ & & & & & & & & 7 & 14 & & 42 & \\
\hline & A & & & 6 & 10 & & & & & & & & \\
\hline \multirow[t]{3}{*}{ Leuctra nigra } & $\mathrm{L}$ & & & 39 & 178 & 6 & 9 & & & 9 & 88 & 7 & \\
\hline & $\mathrm{E}$ & & & 1 & 3 & 2 & & & & & & & \\
\hline & A & & & 14 & 24 & 8 & 3 & & & & & & \\
\hline \multirow[t]{2}{*}{ Leuctra pseudosignifera } & $\mathrm{L}$ & & & & & & & & & & 1 & 1 & \\
\hline & A & & 2 & & & & & & & & & & \\
\hline \multirow[t]{3}{*}{ Nemoura avicularis } & $\mathrm{L}$ & & & 26 & 16 & 1 & 2 & 24 & 79 & 35 & 179 & 159 & 161 \\
\hline & $\mathrm{E}$ & & & 5 & 1 & & & & 1 & & 1 & 1 & 1 \\
\hline & A & & & 15 & 8 & & & & & & & & \\
\hline \multirow[t]{3}{*}{ Nemoura cinerea } & $\mathrm{L}$ & 50 & 13 & 1020 & 1923 & 865 & 64 & 3 & 1 & 3 & 3 & 244 & 17 \\
\hline & $\mathrm{E}$ & 7 & & 9 & 23 & 54 & & & & & & & \\
\hline & A & & & 2 & 99 & 49 & 31 & 1 & & & & & \\
\hline \multirow[t]{3}{*}{ Nemoura dubitans } & $\mathrm{L}$ & 4 & 5 & 10 & & & & & & & & & \\
\hline & $\mathrm{E}$ & & 1 & & & & & & & & & & \\
\hline & A & & & 1 & 17 & 2 & & & & & & & \\
\hline \multirow[t]{3}{*}{ Nemoura marginata } & $\mathrm{L}$ & 8 & & 27 & 397 & 15 & 54 & 36 & 5 & 26 & 90 & 152 & \\
\hline & $\mathrm{E}$ & & & & 3 & 1 & & & & & 1 & & \\
\hline & $\mathrm{A}$ & & & & 69 & 40 & 31 & 2 & & & & & \\
\hline \multirow[t]{3}{*}{ Nemurella pictetii } & $\mathrm{L}$ & 10 & 2 & 16 & 255 & 23 & 104 & 19 & 256 & 29 & 22 & 71 & \\
\hline & $\mathrm{E}$ & 1 & & 1 & 1 & & & & & 2 & & & \\
\hline & $\mathrm{A}$ & & & 4 & 17 & 2 & 13 & 1 & 4 & & & & \\
\hline \multirow[t]{2}{*}{ Protonemura intricata } & $\mathrm{L}$ & & & 92 & 758 & 33 & 12 & 2 & & & & & \\
\hline & A & & & & 1 & & & & & & & & \\
\hline \multirow[t]{2}{*}{ Protonemura meyeri } & $\mathrm{L}$ & & & & & & & & 1 & 4 & & 10 & \\
\hline & A & & & 8 & & & & & & & & & \\
\hline \multirow[t]{2}{*}{ Taeniopteryx nebulosa } & $\mathrm{L}$ & & & & & & & & & & 3 & & \\
\hline & $\mathrm{E}$ & & 4 & & & & & & & & & & \\
\hline Taeniopteryx schoenemundi & $\mathrm{E}$ & & 8 & & & & & & & & & & \\
\hline
\end{tabular}


while the water quality of larger watercourses seems to be too bad to allow the occurrence of stoneflies. Recently, stoneflies were observed again in larger watercourses such as the Mangelbeek, the Grote Nete and the river Meuse, however, each observation consisted of only one larvae, which might indicate that their occurrence in these watercourses is due to drift. The reappearance in larger rivers is a still a hopeful sign because it indicates that these watercourses can be recolonised when these watercourses obtain a good water quality. However, most remaining stonefly populations are especially vulnerable since they are restricted to springs located in isolated forest remnants. Species that are restricted to large streams, such as Isogenus nubecula, do not stand a change in Flanders. Zwick (1992) even reported that all potamal species in Central Europe are either extinct or extremely endangered.

Less oxygen is soluble in warm water compared to cold water and species developing during summer are therefore especially vulnerable to pollution. In Flanders, the only species of which the main growth period of the larvae takes place during summer, is Leuctra fusca. However, this species is on the verge of extinction in Flanders as it is restricted to the Zwarte Beek, a small Campine brook. Apart from L. fusca, also larvae of the ubiquitous species Nemurella pictetii are often active during summer. However, $N$. pictetii can be partly bivoltine (Nesterovitch \& Zwick 2003), as reflected by the two activity peaks in April and August, which might explain why this species is still relatively abundant.

\section{Conclusion}

Flanders is densely populated and sewage sludge only partly passes through water treatment plants before it is discharged, while the intensive agriculture also causes a heavy pressure. In order to obtain a good water quality in all water bodies, which should be the case by 2015 according to the EWFD, there is still a lot of work to be done. At the moment, most attention is focused on the watercourses with the poorest water quality, however, ameliorating water quality from bad to poor or moderate will not help populations of sensitive organisms such as stoneflies. A first step should be to protect the sites which still have a high water quality and contain sensitive organisms. In addition, most suitable habitats are now isolated and therefore populations are extremely vulnerable to extinction, while recolonisation is hardly possible. Once a species is extinct in Flanders, it is now unlikely it will be able to return because also in the Netherlands and the northern part of Wallonia, stone- flies are severely threatened. Therefore, also intentional interventions are needed that are directed to the connection of isolated populations by solving the present bottlenecks that prevent the necessary expansion of the remaining populations. It can only be hoped that the EWFD will encourage the member states to undertake the necessary steps to achieve an ecological quality that is sufficient to support sustainable populations of sensitive organisms such as stoneflies.

\section{Acknowledgements}

In the first place, we would like to thank the Royal Belgian Institute of Natural Sciences, the Flemish Environment Agency, Gembloux Agricultural University, the Flemish Entomological Society and the Workgroup Invertebrates Dender-area for the opportunity to study their collections. For the help during the study of the collections, we would like to thank Rose Sablon, Jackie Van Goethem, Jérôme Constant, Patrick Grootaert and Baudewijn Goddeeris (Royal Belgian Institute of Natural Sciences), Erik Ghyselbrecht, Joost Mertens, Lieven Detemmerman, Thierry Warmoes, Christophe Maes, Saskia Lammens and Wim Gabriels (Flemish Environmental Agency), Thierry Vercauteren (Provincial Institute for Hygiene, PIH), Jeannine Bortels (Gembloux Agricultural University), Andy Dedecker, Tom D'Heygere and Ans Mouton (Ghent University). We are also grateful to Bram Koese (European Invertebrate Survey-Nederland) and Monique Korsten (Waterschap Roer en Overmaas) for reporting some observations and Karlien De Temmerman (Research Institute for Nature and Forest) for the help during sampling. Finally, we would like to thank Tim Adriaens from the Research Institute for Nature and Forest for plotting the distribution maps. Koen Lock is currently supported by a post-doctoral fellowship from the Fund for Scientific Research (FWO-Vlaanderen, Belgium).

\section{References}

Aubert J. 1950. Note sur les Plécoptères européens du genre Taeniopteryx Pictet (Nephelopteryx Klapalek) et sur Capnia vidua Klapalek. Mitt. Schweiz. Entomol. Ges., 13, 303-316.

Aubert J. 1956. Contribution à l'étude des Plécoptères de Belgique. Bull. Inst. Roy. Sci. Nat. Belg., 32(15), 1-12.

Auber J. 1957. Deuxième contribution à l'étude des Plécoptères de Belgique. Bull. Inst. Roy. Sci. Nat. Belg., 33(27), 1-3.

Aubert J. 1959. Plecoptera. Insecta Helvetica, 1, 1-140.

Bal D., Beije H.M., Fellinger M., Haveman R., Van Opstal A.J.F.M. \& Van Zadelhoff F.J. 2001. Handboek Natuurdoeltypen. Rapport Expertisecentrum LNV 2001/020, Wageningen.

Claessens E.E.C.M. 1981. The stoneflies (Plecoptera) of the Netherlands. Nieuwsbr. Eur. Invert. Surv. Ned., 10, 73-77.

Demoulin G. 1953. Récoltes d'Ephémères et de Perles dans la region du Bas-Escaut. Bull. Ann. Soc. Entomol. Belg., 89, 124-125.

De Pauw N. \& Vanhooren G. 1983. Method for biological quality assessment of watercourses in Belgium. Hydrobiologia, 100, 153-168.

De Selys-Longchamps E. 1888. Catalogue raisonné des Orthoptères et des Nevroptères de Belgique. Ann. Soc. Entomol. Belg., 32, 103-203.

European Council 2000. Directive 2000/60/EC of the European Parliament and of the Council of 23 October 2000 establishing a framework for Community action in the field of water policy. Official Journal of the European Communities L327, 22 December 2000, Brussels. 
Gabriels W., Goethals P.L.M. \& De Pauw N. 2006. Development of a multimetric assessment system based on macroinvertebrates for rivers in Flanders (Belgium) according to the European Water Framework Directive. Verh. Int. Ver. Theor. Angew. Limnol., 29, 2279-2282.

Grootaert P. \& Verbeke K. 1983. Nemoura cinerea Retzius (Plecoptera) toch nog aanwezig in West-Vlaanderen. Bull. Ann. Soc. Entomol. Belg., 119, 300.

IBN 1984. Biological Quality of Watercourses. Determination of the Biotic Index Based on Aquatic Macroinvertebrates. NBN T92-402 (in Dutch and French). Belgian Institute of Normalization, Brussels, Belgium, 11 p.

Illies J. 1955. Steinfliegen oder Plecoptera. Tierw. Deutschl. Angr. Meeresteile, 43, 1-150.

IUCN Species Survival Commission 1994. IUCN Red List categories. IUCN, Gland.

Jochems H., Schneiders A., Denys L. \& Van Den Berghe E. 2002. Typology of surface waters in Flanders. Final report of the project VMM.KRLW-typologie (in Dutch), Institute of Nature Conservation, Brussels

Koese B. 2008. De Nederlandse steenvliegen (Plecoptera). Entomologische Tabellen 1, 1-158.

Lestage J.A. 1921. Etudes sur la biologie des Plécoptères II. La larve de Nephalopteryx nebulosa L. Ann. Biol. Lacustre, 10, 231-260.

Lestage J.A. 1938. Le nombre variable d'apophyses abdominals sur les exuvies de Taeniopteryx (Nephelopteryx) nebulosa L. (Plécopt.).
Bull. Ann. Soc. Entomol. Belg., 78, 353.

Lestage J.A. 1938. Etudes sur la biologie des Plécoptères (1): remarques critiques sur le genre Taeniopteryx Pict. (olim Nephalopteryx Klp.), et sur la différenciation des larves connues en Europe. Bull. Ann. Soc. Entomol. Belg., 78, 439-452.

Maes D., De Bruyn L. \& Kuijken E. 2003. Red List criteria in Flanders. In: de Iongh H.H., Bánki O.S., Bergmans W. \& van der Werff M.J. (eds) Harmonization of Red lists in Europe. Proceedings International Seminar, 27-28 November 2002, The Netherlands Foundation for International Nature Protection, Mededelingen No. 38, Leiden.

Maes D. \& Van Swaay C.A.M. 1997. A new methodology for compiling national Red Lists applied to butterflies (Lepidoptera, Rhopalocera) in Flanders (N-Belgium) and the Netherlands. J. Insect Conserv., 1, 113-124.

Nesterovitch A. \& Zwick P. 2003. The development of Nemurella pictetii Klapalek (Plecoptera: Nemouridae) in springstreams in central Europe. Limnologica, 33, 231-243.

Ter Braak C.J.F. 1988. CANOCO - a FORTRAN program for canonical community ordination by (partial) (canonical) correspondence analysis, principal components analysis and redundancy analysis (version 2.1). Agricultural Mat. Group, Ministry of Agriculture and Fisheries (Netherlands), Wageningen.

Zwick P. 1992. Stream habitat fragmentation - a threat to biodiversity. Biodivers. Conserv., 1, 80-97. 
